\title{
The Implementation Of Viewboard Of The Head Of Department As A Media For Student Information Is Worth Doing Final Research
}

\author{
Po Abas Sunarya ${ }^{1}$, Qurotul Aini ${ }^{2}$, Adrian Sean Bein ${ }^{3}$, Pipit Nursaputri ${ }^{4}$ \\ Universitas Raharja ${ }^{1,2,4}$, Queensland University of Technology ${ }^{3}$ \\ Indonesia, Australia \\ e-mail:_ini@raharja.infol ${ }^{1}$,.10132350@qut.edu.au², pipit.nursaputri@raharja.info³
}

To cite this document:

Aini, Q., Sunarya, P., Bein, A., \& nursaputri, P. (2019). The Implementation Of Viewboard Of The Head Of Department As A Media For Student Information Is Worth Doing Final

Research. IAIC Transactions on Sustainable Digital Innovation (ITSDI), 1(1), 18-25.

Retrieved from https://aptikom-journal.id/index.php/itsdi/article/view/1

\begin{abstract}
Submission of information is a very important thing that is owned by a system. The system that is made very well will be able to convey good and clear information to its users so that it can communicate well. The more rapid technology has been used by several educational institutions, especially universities, to support the existing learning system. For students who have fulfilled the requirements for conducting final research, it is appropriate to declare to carry out the final research. But the head of the department is still required to come to campus to declare that the student is eligible or not to do the final research. Therefore we need a system that can provide convenience for the Head of Department to declare that students are eligible to do final research that can be accessed online so that it can be accessed anywhere and anytime by the Head of Department and does not need to come to campus because the system still uses local networks. In order to provide convenience and effectiveness for the Head of Department to check and provide eligibility for students eligible for final research which then leads to the maximum service to students. In conducting research research methods used in this study namely observation, interviews and literature study In the process of developing the system the writer uses 4 stages, namely problem identification, planning, designing prototypes and reviewing prototypes. Evidenced by the viewboard of the head of the department of service to students, it was very well fulfilled.
\end{abstract}

Keywords: Viewboard, Information, Head of Department

\section{Introduction}

Submission of information is a very important thing that is owned by a system. The system that is made very well will be able to convey good and clear information to its users so that it can communicate well. Submission of good information is information obtained from data that is clear or not fake. The data submitted must be clear because so that the information delivered can be captured properly by the users.

The more rapid technology has been used by several educational institutions, especially universities, to support the existing learning system. Likewise when the process of selecting

eligible students to conduct final research to complete their learning. For students who have fulfilled the requirements for conducting final research, it is appropriate to declare to carry 


\section{IAIC Transactions on Sustainable Digital Innovation (ITSDI)}

Vol. 1 No. 1 October 2019

out the final research. But the head of the department is still required to come to campus to declare that the student is eligible or not to do the final research.

Therefore we need a system that can provide convenience for the Head of Department to declare that students are eligible to do final research that can be accessed online so that it can be accessed anywhere and anytime by the Head of Department and does not need to come to campus because the system still uses local networks. In addition, proper student data for conducting final research must be able to update automatically, not relying on the admin to update student data.

In order to provide convenience and effectiveness for the Head of Department to check and provide eligibility for students eligible for final research which then leads to the maximum service to students. Therefore there is a Viewboard Head of Department who will make the performance of department heads more effective and efficient.

\section{Research Method}

In conducting a study there are several research methods used to launch the research process so that the desired goals can be achieved. There are several research methods used in this study, namely observation, interviews and literature.

The author makes observations to a university to see the system used by the head of department to see which students are eligible to do the final research. Furthermore, the author conducted interviews with stakeholders to obtain some data for research purposes. In the system development process the writer uses 4 stages, namely problem identification, planning, designing prototypes and reviewing prototypes. The following is the design of the research method used.

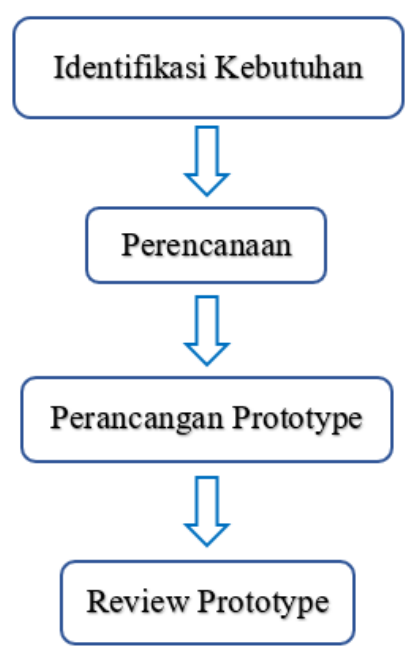

Figure 1. Stages of research methods

1. Identification of Needs

This method aims to take a top-down approach to get an overview of the information scenario that will be presented on the Viewboard or Dashboard.

2. Planning

This method is needed to analyze the data that has been obtained from the results of identification needs

3. Prototype design

The design aims to see the suitability between the needs of users and the system that was planned before being implemented in real terms. 


\section{IAIC Transactions on Sustainable Digital Innovation (ITSDI)}

Vol. 1 No. 1 October 2019

\section{Prototype Review}

The review process is needed to make improvements to the system if there is a discrepancy with the user's needs.

\section{Literature Review}

Not only the 4 needs above, efforts in supporting this research and in order to build the headboard's system of viewboard so that it can be used properly the author uses a literature study method that is looking for similar studies to support this research, there are several literature reviews prepared to avoid repetition, and continue the research that has been done previously. Some literature reviews include the following:

1. The research entitled "Viewboard Implementation Based on Javascript Interactive Charts on Higher Education E-commerce Websites" was conducted by the Aini Qurotul in 2019. This study discusses the application of graphics as a medium for presenting information on Raharja Internet Cafe's viewboard, causing top management and employees to know regarding sales reports more easily, thus, it can be concluded that the use of Highcharts graphics can improve quality

2. The research entitled "Implementation of Yii Framework-Based Advisory Scoring Viewboard System at Pessta + in Higher Education" conducted by Padeli in 2018, discusses the Advisory Assessment system is very important to facilitate lecturers in providing guidance assessments aimed at TA students and Thesis students. In the assessment the supervisor can be accessed on the PESSTA + system so that it becomes more systematic, organized, can be accessed anywhere online.

3. This research was conducted by Untung Rahardja in (2019), entitled "Implementation of Yiboard Framework-Based Validation of Viewboard Status at STATUS + in Higher Education". The study discusses viewboard is an application system that can monitor or display an information in graphical form, making it easier for users to control and set goals to be achieved. In addition, the Viewboard can also be used as a means to evaluate the process on the system that is running at this time. With the presence of Viewboard, it is expected to be able to solve existing problems, namely to provide information about student performance on the objective assessment validation status in the PESSTA + system.

4. The research conducted by Ely Susanti (2018) is titled "Viewboard Implementation in Supporting Information Spread by Presenting Artificial Informatics at Higher Education". This study describes the application of Viewboard applications for educational institutions as a module to assist leaders in making strategic decisions. Viewboard applications are developed based on existing databases on other systems as a data warehouse. In its application, the Viewboard application was built using the PHP programming language for front-office interfaces with the concept of Artificial Informatics as a result of the presentation of processed database queries.

5. The research conducted by Khanna Tiara in 2016 with the title "Implementation of Yiboard-Based Viewboard GO + as a Media for Monitoring Student Payments" discusses the $\mathrm{GO}+$ viewboard as a place and container of information from data in the $\mathrm{GO}+$ database so that later will display accurate and up-to-date information related to student payments. With this viewboard goal, it can also make it easier for staff to monitor student data.

6. The research was conducted by Kevin in 2018 with the title "Implementation of Viewboard as Information Media for Thesis Session at PESSTA + in Higher Education". The study explains that viewboards are expected to provide quality and reliable information, therefore, facilities are needed to provide solutions, evaluate processes and monitor the performance of ongoing processes. By designing a Viewboard, it is 


\section{IAIC Transactions on Sustainable Digital Innovation (ITSDI)}

Vol. 1 No. 1 October 2019

expected to provide an overview of information about the thesis / final assignment activities of PESSTA +.

7. The research is titled "Media Viewboard as a Classification of the Number of Online Decrees at Higher Education" conducted by Eka Purnama Harahap (2017). The study discusses the presence of viewboard media on the Raharja Higher Education decree website that can make it easier for visitors to get information on the classification of numbers from decision letters faster. The benefits of viewboard media can make it easier for visitors to access the amount classification information from updated decision letters at Raharja College.

8. This research was conducted by Randy Wijaya in 2018 with the title "Implementation of Viewboard Technomedia Journal using the iLearning Journal Center system at Universities". This study explains the purpose of Viewboard TMJ is as a place of service information from data that already exists and is related to writing scientific papers or journals so that later it will display valid information can also be easily monitored using computer-based, this makes it easy for admin to manage the data contained in the TMJ into a Viewboard.

\section{Findings}

With the viewboard of the head of the department, it is expected to facilitate the head of department in providing eligibility to students who will take the final research. Head of department does not have to come to campus to access the existing system, because the system can be accessed online. So the department head can access it wherever and whenever.

\subsection{Problem}

Students who have fulfilled the requirements may do the final research. When students want to take final research to complete their studies, they must get approval from the head of department. Then the department head agreed and chose the supervisor for the student.

However, the system used by the head of department to see the requirements of a student is feasible and choose a supervisor who still uses the local network and the department head must come to campus to access the system.

\subsection{Research Implementation}

Now there is a headboard viewboard which is very useful for the head of department. Systems that can be accessed online make it easier for department heads to access them wherever and whenever. Even the head of department can see which students are eligible for the final research and choose the supervisor for the student. Later the department head only signed the files to be submitted to the service department.
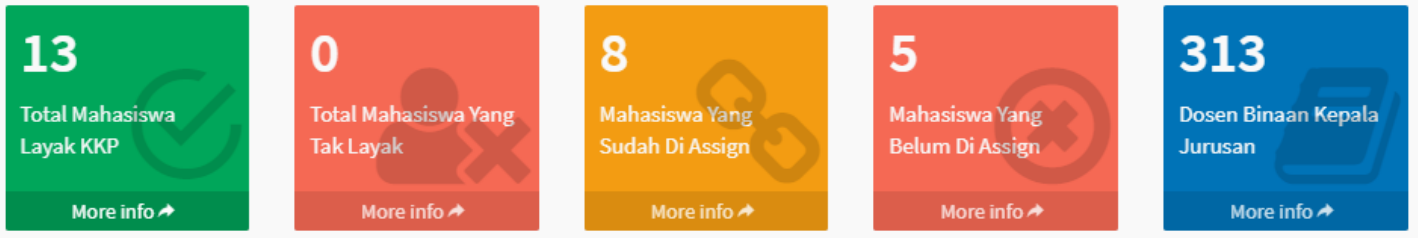

Figure 2. Viewboard All Display 


\section{IAIC Transactions on Sustainable Digital Innovation (ITSDI)}

Vol. 1 No. 1 October 2019

Figure 2. is a viewboard view that provides information to the department head. In the viewboard, there is information about the total number of eligible and non-eligible students conducting final research. Not only that, there is also the total information of students who have been and have not been assigned to choose the supervisor when conducting the final research.

Viewboard Jenjang Sarjana
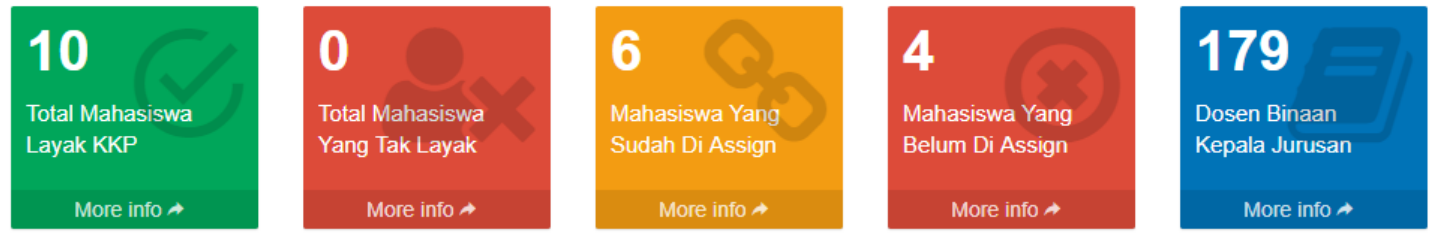

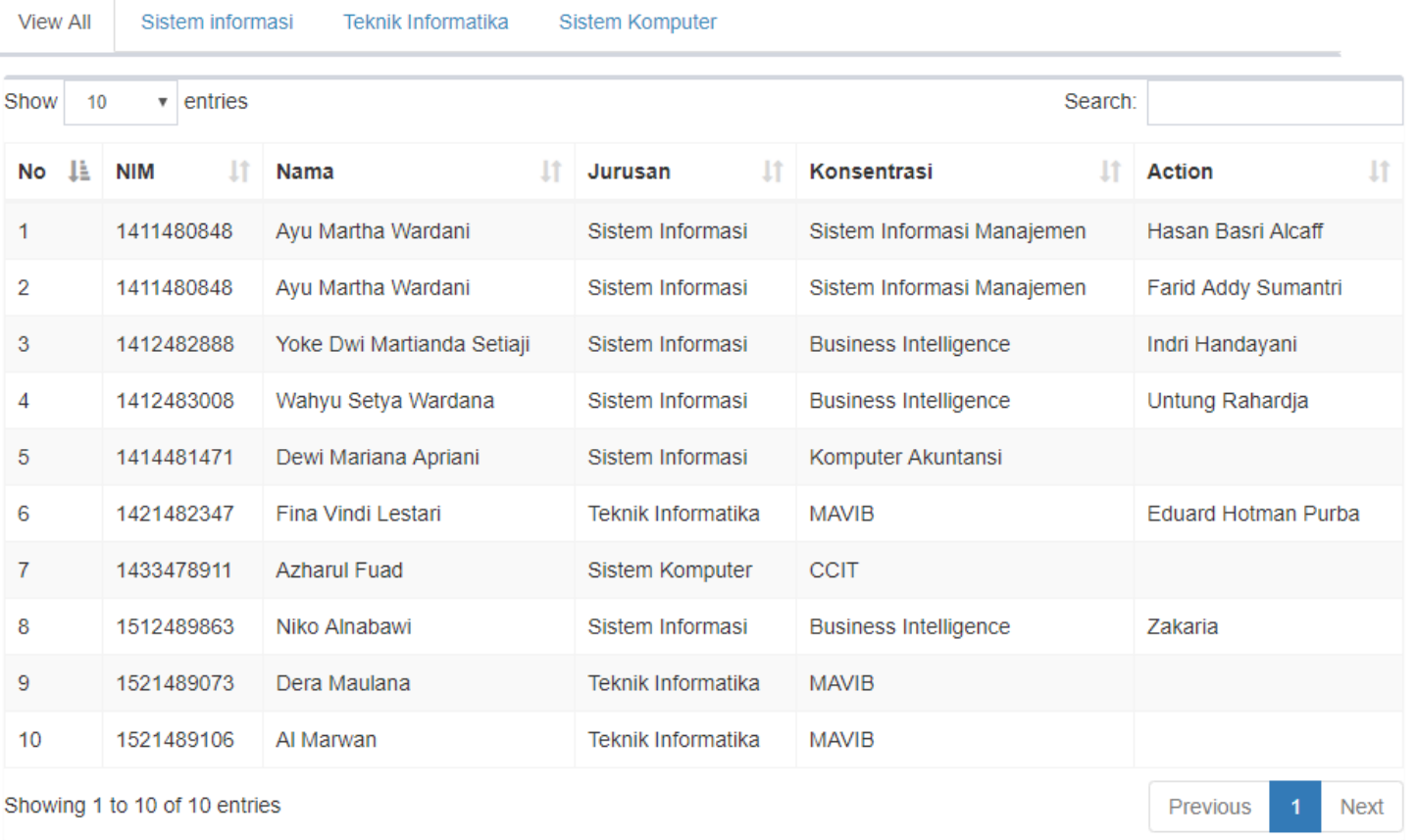

Figure 3. Viewboard undergraduate level

Figure 3. above is a viewboard at the undergraduate or bachelor level. On the viewboard the display is not much different from the viewboard display all. There is information on the total number of eligible and non-eligible students conducting final research. Not only that, there is also the total information of students who have been and have not been assigned to choose the supervisor when conducting the final research. But in the view above there is a table of undergraduate students who have been declared eligible and their supervisors are selected with information on the names, names, majors, and concentration of the student. 
IAIC Transactions on Sustainable Digital Innovation (ITSDI)

Vol. 1 No. 1 October 2019

\section{Viewboard Jenjang Diploma}
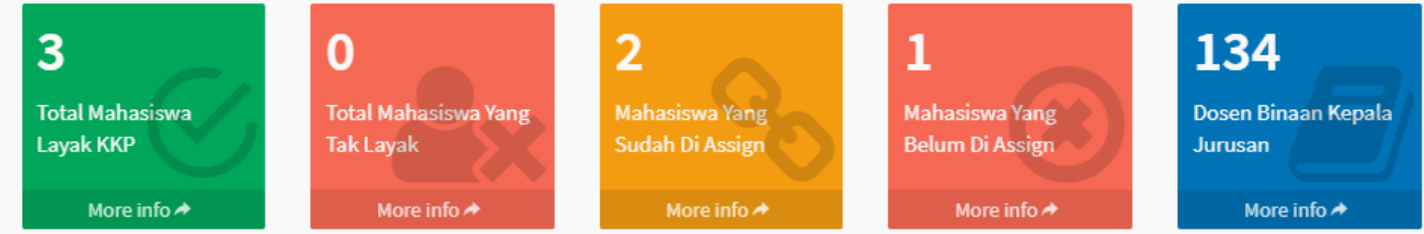

View All Manajemen Informatika $\quad$ Sistem Informasi D3 $\quad$ Teknik Informatika D3

\begin{tabular}{|llllll}
\hline No & NIM & Nama & Jurusan & Konsentrasi & Dosen Pembimbing \\
\hline 1 & 1414382008 & Taufan & Manajemen Informatika & Web Graphic Design & Imam Sujarwo \\
\hline 2 & 1414481686 & Monikawati & Sistem Informasi D3 & Komputerisasi Akuntansi & Zakaria \\
\hline 3 & 1433376120 & Sandra & Teknik Informatika D3 & Artificial Informatics \\
\hline
\end{tabular}

Gambar 4. Viewboard jenjang diploma

Gambar 4. merupakan tampilan yang tidak jauh berbeda dengan tampilan viewboard untuk jenjang sarjana. Yang membedakan ialah tampilan pada viewboard tersebut adalah diperuntukkan untuk jenjang diploma.

\section{Daftar Mahasiswa Layak KKP}
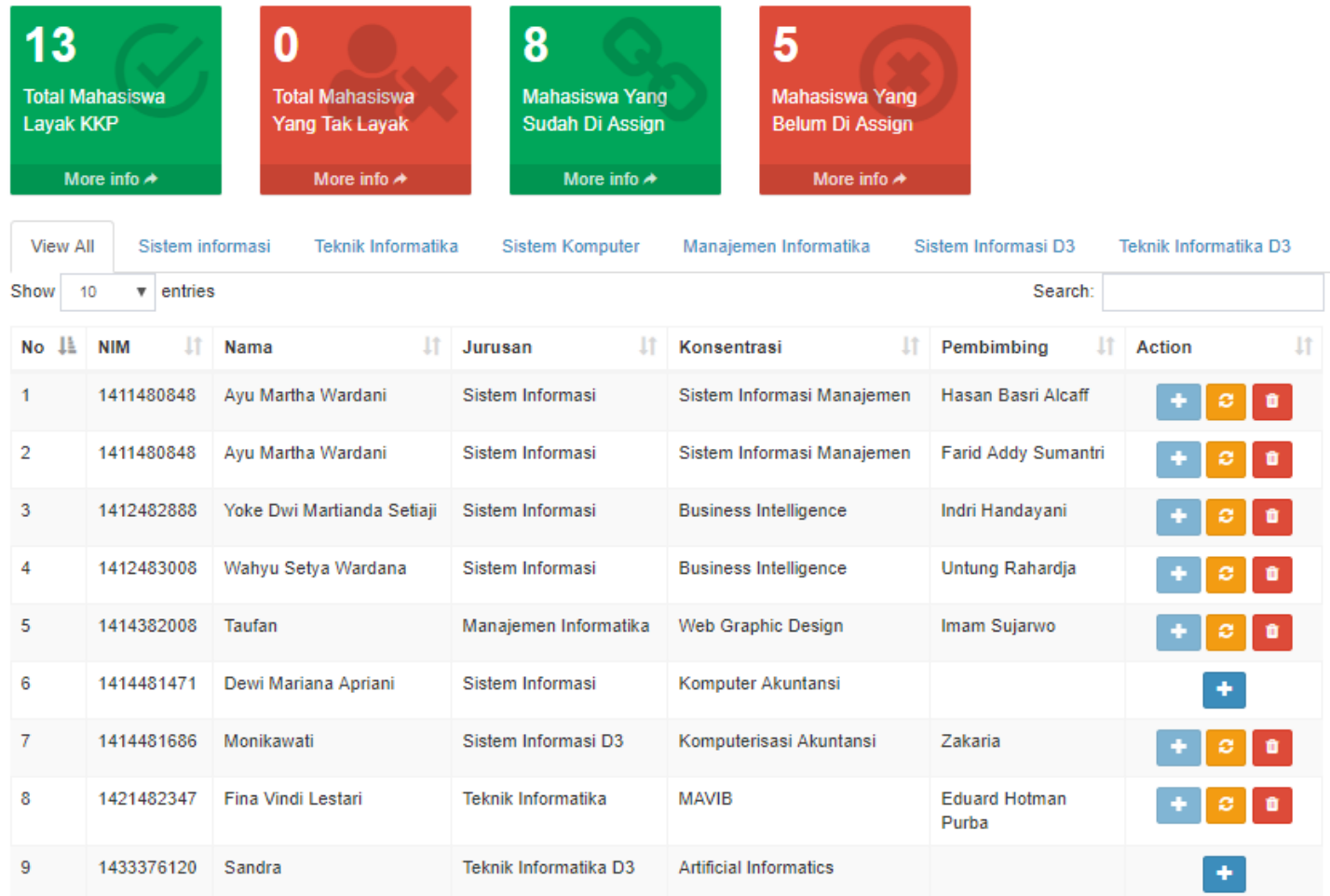

Figure 5. Viewboard display of students worthy of final research

Figure 5. is a display of students who have met the requirements for the final research. 


\section{IAIC Transactions on Sustainable Digital Innovation (ITSDI)}

Vol. 1 No. 1 October 2019

The head of the department can see and directly choose the supervisor for students. There is an action button on the table if the head of the department has chosen the name of the supervisor, then the name of the supervisor will appear in the student row.

\begin{tabular}{|c|c|c|c|}
\hline No & NID & Nama Dosen & Jumlah Mahasiswa Bimbingan \\
\hline 1 & 00002 & Zakaria Ir. & 2 \\
\hline 2 & 00005 & Imam Sujarwo S.E. & 1 \\
\hline 3 & 00014 & Farid Addy Sumantri S.E.Ak.,M.M. & 1 \\
\hline 4 & 03018 & Eduard Hotman Purba Ir.,M.M. & 1 \\
\hline 5 & 05075 & Hasan Basri Alcaff S.Pd.,MM & 1 \\
\hline 6 & 14018 & Indri Handayani S.Kom.,MTI & 1 \\
\hline 7 & 99001 & Untung Rahardja Ir.,M.T.I. & 1 \\
\hline
\end{tabular}

Figure 6. List of supervisors

Figure 6. is a list of plots of supervising lecturers supervised by the head of the department. In the table there is information about the total number of students guided by one of the lecturers. It can be seen that one lecturer can guide more than one student.

\section{Conclusion}

Communication will not work if there is no information in it. Because that information is indeed very important in communicating. A good system is a system that can convey information properly and correctly according to facts. The head of the department can see information on students who have met the requirements of taking the final research to complete their studies. But the head of the department must come to campus to use the system and see students who have met the requirements. Now there is a headboard viewboard that is very useful for the head of department. No need to come to campus because the system can be accessed online wherever and whenever the head of department wants to access it. Evidenced by the viewboard of the head of the department of service to students, it was very well fulfilled.

\section{References}

[1] Rahardja, U., Handayani, I., \& Wijaya, R. (2018). Penerapan Viewboard Technomedia Journal menggunakan sistem iLearning Journal Center pada Perguruan Tinggi. Technomedia Journal, 2(2), 81-93.

[2] Handayani, I., Febriyanto, E., \& Solichin, K. R. P. (2018). Penerapan Viewboard Sebagai Media Informasi Sidang Skripsi Pada PESSTA+ di Perguruan Tinggi. Technomedia Journal, 2(2), 55-65.

[3] Padeli, P., Febriyanto, E., \& Supyaningsih, F. (2018). Penerapan Sistem Viewboard Penilaian Pembimbing Berbasis Yii Framework Pada PESSTA+ di Perguruan Tinggi. Syntax: Jurnal Informatika, 7(2), 64-76. 
IAIC Transactions on Sustainable Digital Innovation (ITSDI)

Vol. 1 No. 1 October 2019

[4] Rahardja, U., Handayani, I., \& Syoifana, Y. (2019). Penerapan Viewboard Status Validasi Berbasis Yii Framework Pada PESSTA+ Di Perguruan Tinggi. Creative Information Technology Journal, 4(4), 297-305.

[5] Tiara, K., \& Nurhaeni, T. (2016). Penerapan Viewboard GO+ Berbasis Yii Sebagai Media Monitoring Pembayaran Mahasiswa. Technomedia Journal, 1(1), 65-77.

[6] Rahardja, U., Aini, Q., \& Faradilla, F. (2018). IMPLEMENTASI VIEWBOARD BERBASIS INTERAKTIF JAVASCRIPT CHARTS PADA WEBSITE E-COMMERCE PERGURUAN TINGGI. Jurnal Dinamika Informatika, 7(2), 1-18.

[7] Rahardja, U., Pratama, D., \& Susanti, E. (2016). Implementasi Viewboard Dalam Mendukung Penyebaran Informasi Dengan Penyajian Artificial Informatics Pada Perguruan Tinggi. CCIT Journal, 9(03), 251-257.

[8] Rahardja, U., Harahap, E. P., \& Suciani, A. (2017). Media Viewboard Sebagai Klasifikasi Jumlah Surat Keputusan Online Pada Perguruan Tinggi. Technomedia Journal, 2(1), 6981. 